\title{
Food Safety on the Farm: Good Agricultural Practices and Good Handling Practices - Water ${ }^{1}$
}

\author{
Keith R. Schneider, Renee Goodrich Schneider, and Douglas L. Archer ${ }^{2}$
}

\section{Introduction}

Good agricultural practices (GAPs) and good handling practices (GHPs) encompass the general procedures growers, packers and processors of fresh fruits and vegetables should follow to ensure the safety of their product. GAPs usually deal with preharvest practices (i.e., in the field), while GHPs cover postharvest practices, including packing and shipping. This first factsheet covers GAPs and GHPs relating to water use. Seven other Florida Cooperative Extension factsheets will focus on other specific aspects of the GAPs program and how they relate to Florida crops and practices.

Water is one of the most critical components of food safety on the farm and in postharvest handling and processing. Water has the potential to transmit both chemical and biological hazards to fresh produce. It is used in every phase of operation: irrigation, transplant establishment, the application of pesticides and fertilizers, frost protection, product rinsing and washing, direct processing, facility cleaning, cooling operations, and personal hygiene for workers. The application of contaminated water at any of these points can introduce pathogens that could potentially reach the consumer

\section{Microbial Hazards}

Water can be a carrier of many pathogenic strains of microorganisms, including Escherichia coli O157:H7, Salmonella, Shigella, Cryptosporidium, Cyclospora, and hepatitis A, just to name a few. Even small amounts of contamination with some of these organisms can result in foodborne illness. It is often difficult to identify with certainty the source of microbial contamination for fresh produce. In recent outbreaks associated with tomatoes, the problem was traced back to a single packing facility where a dump tank appeared to be the likely source of contamination. Growers and packers must take a proactive role in minimizing these microbial hazards whenever they can.

\section{How to Control Potential Hazards}

The quality of fresh produce is affected by many factors associated with water. The quality of the water used, the ways in which it is used, and the type of the crop being grown all influence and affect the

1. This document is FSHN 06-02, one of a series of the Department of Food Science and Human Nutrition, Florida Cooperative Extension Service, IFAS, University of Florida. First published November 2006. Please visit the EDIS Web site at http://edis.ifas.ufl.edu.

2. Keith R. Schneider, associate professor, Renee Goodrich Schneider, associate professor, and Douglas L. Archer, professor, Food Science and Human Nutrition Department, Cooperative Extension Service, Institute of Food and Agricultural Sciences, University of Florida, Gainesville FL 32611.

The Institute of Food and Agricultural Sciences (IFAS) is an Equal Opportunity Institution authorized to provide research, educational information and other services only to individuals and institutions that function with non-discrimination with respect to race, creed, color, religion, age, disability, sex, sexual orientation, marital status, national origin, political opinions or affiliations. U.S. Department of Agriculture, Cooperative Extension Service, University of Florida, IFAS, Florida A. \& M. University Cooperative Extension Program, and Boards of County Commissioners Cooperating. Larry Arrington, Dean 
potential for contamination. Water quality is extremely important when water comes into direct contact with the edible portion of produce. There may need to be better quality controls in these cases than in cases where water makes minimal contact with the edible portion of produce.

Other factors that influence the potential for a pathogen to get onto or into fresh produce include the condition and type of crop, the length of time between pathogen contact and harvest, and postharvest handling practices. Produce with large surface areas (lettuce, spinach, etc.) and those with rough surfaces (e.g., cantaloupe) may be at greater risk, especially if pathogen contact occurs close to harvest and/or during postharvest handling.

The following areas have been identified by the U.S. Food and Drug Administration (FDA, 1998) as important when assessing water quality. By controlling these areas, a grower/packer/processor may be able to minimize microbial food safety hazards related to water usage in specific operations.

\section{Agricultural Water}

Agricultural water quality varies. For example, water that is clean one day may become contaminated the next, perhaps by wastewater discharge or polluted runoff from upstream livestock operations. Surface water contamination may also affect groundwater (for instance, surface water could infiltrate an old well with a cracked casing).

To help ensure water quality, make sure wells are properly constructed and protected and/or treat water prior to use to reduce microbial loads. Remember, not all interventions are equally effective. Review your operations to gain a clear understanding of which changes will have the greatest impact.

\section{General Considerations}

There are many sources of agricultural water. Flowing surface water can come from rivers, streams, irrigation ditches, and open canals. Water can also come from impoundments, such as ponds, reservoirs, lakes, and wells. Lastly, water may be obtained from a municipal supply. Generally speaking, groundwater is less likely to be contaminated than surface water, but under certain conditions, shallow, improperly constructed, or older wells may become contaminated from surface water. In order to prevent contamination:

- Maintain wells in good working condition.

- Review existing practices and conditions to identify potential sources of contamination.

- Be aware of current and historical uses of land.

- Make sure that feedlots, animal pastures, and dairy operations in the region use and maintain fences or other barriers to minimize animal access to shared water sources.

- Find out if manure is applied to land by many farms in the region.

- Find out how local rainfall patterns and topography affect the likelihood that contaminated runoff from these operations will reach surface waters.

- Make sure that controls are in place to minimize contamination of agricultural waters from other farm or animal operations.

- Consider practices that will protect water quality.

- Consider irrigation water quality and use.

\section{Microbial Testing of Agricultural Water}

Microbial testing gives growers only a "snapshot" of water quality. For example, a single test performed last month would have limited predictive value for this month if a rainfall event happened to wash cattle runoff into your tomato field. Growers who are concerned about water quality should first focus their attention on GAPs to maintain and protect the quality of their water sources.

However, periodic testing still can be a useful tool. Growers can test their water supply for microbial contamination on a periodic basis, using standard indicators of fecal contamination, such as $E$. coli. Make sure these tests are performed by a 
qualified commercial, state, or local government laboratory.

Remember, even if your results do not show bacterial safety concerns, this does not necessarily mean that there is an absence of protozoa and/or viruses. Also remember that water quality, especially surface water quality, can vary with time. Finally, keep in mind that most tests will not tell you if specific pathogens are present in low numbers. Growers should consult local water quality experts, such as state or local environmental protection or public health agencies, Extension agents, or land grant universities, for advice that is appropriate for their individual operations.

\section{Processing Water}

Fruits and vegetables are highly susceptible to contamination during postharvest handling due to the high degree of water-to-produce contact. Water can be useful in reducing potential contamination, but may also serve as a source of contamination or cross-contamination. If processing water is reused, microbial contamination can build up and result in the contamination of a large batch of produce.

Practices should be instituted to ensure that water quality is adequate both at the start and at the end of all postharvest processes.

\section{General Considerations}

Follow good manufacturing practices (GMPs) to minimize microbial contamination from

processing water. GMPs for water used for food and food contact surfaces in processing facilities are in Title 21 of the Code of Federal Regulations (CFR), sections 110.37(a) and 110.80(a)(1). These GMPs are in place for all manufacturers, packers, and processors of food products, and can be found online through an electronic search by going to http://www.access.gpo.gov/cgi-bin/ cfrassemble.cgi?title $=200121$.

Consider practices that will ensure and maintain water quality.

- Perform periodic water sampling and microbial testing.
- Change water as necessary to maintain sanitary conditions. Develop SOPs (standard operating procedures or sanitary operating plans), including water change schedules, for all processes that use water.

- Clean and sanitize water contact surfaces, such as dump tanks, flumes, wash tanks, and hydrocoolers, as often as is necessary to ensure the safety of produce.

- Install backflow devices and legal air gaps as needed (such as between potable water fill lines and dump tank drain lines) to prevent the contamination of clean water by potentially contaminated water.

- Routinely inspect and maintain equipment designed to assist in maintaining water quality, such as chlorine injectors, filtration systems, and backflow devices, in order to ensure efficient operation.

\section{Antimicrobial Chemicals}

Another point to remember is that the best offense may be a good defense. Preventing a pathogen from getting onto your product in the first place is preferable to trying to remove one. Antimicrobial chemicals used in processing water can be useful in reducing microbial build-up and may reduce the potential for contamination.

The effectiveness of an antimicrobial agent depends on many factors too numerous to mention here. If you want more information, refer to Chlorine Use in Produce Packing Lines (http://edis.ifas.ufl.edu/CH160), a factsheet by Ritenour et al. (2002). There are many different chemicals and methods you can use: sodium hypochlorite (food grade bleach), ozone, ultraviolet radiation, chlorine dioxide, trisodium phosphate, and organic acids (such as lactic and acetic acids).

Operators should consider which options are most appropriate for their individual operations. Contact chemical companies that sell antimicrobial chemicals for additional technical assistance. 


\section{Washwater}

No washing process can remove all pathogens, but every additional cleansing step helps. Since a lot of microbial contamination is on the surface of fruits and vegetables, proper washing can be an important part of your process.

Another reason for extra care at this step is that if pathogens are not removed or controlled here, they can contaminate other produce and equipment, creating a bigger problem. A number of postharvest processes (such as hydrocooling, use of dump tanks, and flume transport) use a lot of water, meaning that there is a high risk of cross-contamination. Packers should follow good manufacturing practices to maximize the potential for these processes to assist in cleaning produce.

- Use appropriate wash methods.

- Maintain the efficacy of wash treatments.

- Consider the washwater temperature for certain produce.

- Consider alternative treatments for water-sensitive produce.

\section{Cooling Operations}

Cooling is a step that is often overlooked when trying to reduce microbial contamination. Different methods can be employed, including the uses of water, ice, and forced air. The best method depends on the fruit or vegetable being processed. In most cases, air cooling runs the lowest risk of contaminating your product. If you use water and/or ice, remember that the operator is a potential source of contamination. If you reuse your water in produce cooling, remember that microbial contamination can build up. Good practices may include the following:

- Cool the product quickly and maintain temperatures that promote optimum produce quality.

- Maintain air cooling equipment and cooling areas.
- Consider the use of antimicrobial chemicals in cooling water.

- Keep water and ice clean and sanitary.

- Manufacture, transport, and store ice under sanitary conditions.

- Equipment should be clean and sanitary.

\section{References}

Ritenour, M.A., S.A. Sargent, and J.A. Bartz. 2002. Chlorine use in produce packing lines. University of Florida Document HS-761. http://edis.ifas.ufl.edu/CH160 (accessed October 12, 2006).

United States Food and Drug Administration. 1998. Guide to minimize microbial food safety hazards for fresh fruits and vegetables. FDA/CFSAN Web site. http://www.cfsan.fda.gov/ dms/prodglan.html (accessed October 12, 2006).

United States Department of Agriculture. 2000. U.S. national standards on organic agricultural production and handling. USDA NOP Web site. http://www.ams.usda.gov/nop/indexIE.htm (accessed October 12, 2006). 